\title{
User Innovation: State of the Art and Perspectives for Future Research
}

\section{Maria Roszkowska-Menkes ${ }^{1}$}

\begin{abstract}
Given the rising role of users in innovation processes and the increasing amount of research in this field the aim of this paper is to explore the limits of our understanding of the user innovation (UI) concept. In doing so, the study addresses four basic questions: (1) Why do users create and share innovation? (2) Who is the userinnovator? (3) What type of innovation do users create? (4) How do users innovate? The results of a systematic literature review identified the main research streams on user innovation, together with weaknesses of past research and perspectives for future studies.
\end{abstract}

Keywords: co-creation; collaborative innovation; mass customization; user innovation; user-driven innovation.

\section{INTRODUCTION}

For decades innovation research has focused primarily on manufacturers as the major source of innovation in the economy. This dominance of a manufacturer-centric innovation model was challenged by von Hippel in the 1970s, who first paid attention to the role of users as innovators of scientific instruments (von Hippel, 1976). Since this seminal work user innovation (UI) has become one of the key topics in innovation management research. Von Hippel (2011) defines user innovation as the "one that a firm or individual makes to use themselves". In this model, users are no longer "pure" consumers of products created and supplied by producers, but they design and often manufacture products and services for themselves. User innovation is based on three key premises: (1) users have unique information about their needs; (2) when enabled they will create solutions to those needs; (3) they often freely reveal those solutions to others (Piller \& West, 2014). Users, both

1 Maria Roszkowska-Menkes, Ph.D., Warsaw School of Economics, SGH, Department of Management Theory, Al. Niepodległości 162, 02-554 Warsaw, Poland, e-mail: maria.roszkowska-menkes@sgh.waw.pl. 
intermediate and consumers, play a central role in innovation processes in various sectors - from oil refining (Enos, 1962), chemical (Hollander, 1965) and the semiconductors industry (von Hippel, 1988) to software (von Krogh \& von Hippel, 2006) and sports equipment development (Franke \& Shah, 2003). The phenomenon of UI has recently been strongly reinforced by the continuing advances in computer and communications capabilities (von Hippel, 2005) that increase access to information within society (Lakhani \& Panetta, 2007) and drive heterogeneity of user demand (Franke \& von Hippel, 2003). The latter can be observed especially within the new generation of consumers, born and raised in the digital era, who demand customized products and services or at least the freedom to modify them accordingly to their needs (Tapscott \& Williams, 2006). Empirical studies show that many users-from 10 per cent to nearly 40 per cent- engage in developing or modifying products. Consumers are transforming into prosumers whose solutions, which are usually the fruit of cooperation within globally dispersed communities, can successfully compete with fully commercial products.

Von Hippel's seminal study has opened up an extremely fertile field of research that has extended to many diverse areas including innovation communities and open source (von Krogh \& von Hippel, 2006), entrepreneurship (Shah \& Tripsas, 2007), mass customization (Pine, 1993), open innovation (Piller \& West, 2014), and policy and law making (Fisher III, 2010). On the one hand this diversity shows that users are gaining vast recognition as important sources of value for companies and society at large, while on the other hand it leads to conceptual ambiguity and confusion. Further development in this area requires a comprehensive literature review that would provide clarification and explore the limits of our understanding of user innovation.

The aim of this paper is twofold. First, is to review the growing literature on $\mathrm{UI}$ and investigate major research streams in the field. Second, is to identify weaknesses and gaps in the previous studies and suggest directions for future research. In doing so, the study addresses four very general questions that enable the organization of the vast literature on $\mathrm{UI}$ and embrace this extremely rich concept:

1. Why do users create and share innovation?

2. Who is the user-innovator?

3. What type of innovation do users create?

4. How do users innovate? 
To the author's best knowledge there has been only one comprehensive literature review on user innovation published so far. Bogers, Afuah, and Bastian (2010)explore the role that users play during innovation and review the main journals in management in general and management of technology in particular, as well as other publications that explore the sources of innovation. In their analysis the authors focus on four key dimensions-research questions, methods and findings, theoretical perspectives, and assumptions. They identify different research streams within the literature, and some of the key unexplored questions in the area. The previous include the distinction between studies exploring users' innovation activity and those focused on producers taking advantage of users as innovators. In both categories two research streams have been differentiated, respectively: intermediate users as innovator vs consumer user as innovator, and user as post-implementation adapter vs user as source of innovation-related knowledge. It is argued that the identified streams are too broad and fail to highlight some of the important forms of UI, such as innovation by ordinary users, mass customization, firmhosted communities and community innovation that, as being determined by different factors and producing different outcomes, should be tackled separately. With regard to further research opportunities Bogers et al. (2010) argue that future studies on UI should focus on user motivation, on types of users and their roles in innovation processes, on types of innovation created by users and their impact on industry dynamics, on clarification of the users and innovations definitions, and finally on empirical validation of the phenomenon.

The study presented in this paper builds on and contributes to the previous review in two ways. First by analysing the literature from the perspective of the four very general research questions it is hoped to identify more specific themes within the field. Second, the selected questions for the study of more recent research papers have enabled an investigation into whether major weaknesses and gaps in the UI literature, identified so far, have been tackled and to provide directions for further exploration in the area.

The remainder of this paper is organized into three sections. The first section introduces the research method. The second section presents the results of the relevant literature review conducted with respect to four research questions, which are followed by the identification of challenges for further development of the UI concept and opportunities for future research. Final remarks are presented in the conclusion section. 


\section{RESEARCH METHODS}

To identify relevant research for the analysis the author used systematic review methodology. While selecting the method, the research questions, as well the form of the findings presentation, the author consulted the methodology presented in Tranfield, Denyer, and Smart (2003) and similar literature reviews on the related field of open innovation (Chesbrough \& Bogers, 2014; Dahlander \& Gann, 2010; Huizingh, 2011; West \& Bogers, 2014). The search was conducted within Thomas Reuters Web of Science for publications that had "user innovation" in the topic field. The topic field includes the title, key words and abstract in the database. The chosen database is generally considered the most comprehensive for scholarly work, includes the most prominent journals in a field (Dahlander \& Gann, 2010) and enables the identification of most influential and recognized studies. The search was conducted on April 3, 2015. It included articles, abstracts, editorials, book chapters, interviews and reviews. In order to capture research conducted within management sciences the results were limited to the Social Sciences Citation Index (SSCI).

The search yielded 138 articles. After abstract analysis 7 papers that actually did not concern user innovation were excluded from the original list. Bibliometric analysis was conducted on the final list of 131 articles in order to investigate the growth, scope and breadth of UI research. Although the origins of research on user innovation date back at least to the 1960s, it was not until recently that the field started to be intensively explored by scholars. Out of 131 identified articles 118 were published after 2005. The topic has been discussed in some of the best peer-reviewed journals, just to name few: Research Policy, Management Science, Organization Science and International Journal of Technology Management. In alphabetical order, the list of authors that contributed the most to the field include: Franke, von Hippel, von Krogh, Lakhani, and Piller.

The next step focused on the identification of the most influential studies in the area - 50 articles with the largest number of citations were selected from the final list to serve as the basis for a thorough review of UI literature in reference to the research questions. Such citation counts are biased towards earlier publications and cannot identify more recent work that will be influential in the future. The latter are, however, taken into consideration in the discussion section focused on new research streams. Finally, in order to learn more about the origins of the concept under study, backward reference 
search within 50 selected papers was conducted. This yielded 25 additional studies that were also reviewed thoroughly using the four general questions.

\section{LITERATURE REVIEW}

\section{Why do users create and share innovation?}

One of the key issues intensively explored in the past research on user innovation related to motives that drive users to create and share innovation. The following section provides overview of the results of these studies.

\section{Utilitarian motives - addressing heterogeneity of needs}

User needs for a particular type of product or service are often heterogeneous (Franke \& von Hippel, 2003), and it is difficult and costly for firms to understand them (von Hippel \& Katz, 2002). Users with unique needs, who can either buy a custom-made product from a specialist supplier or innovate themselves, often choose the latter. One reason for that relates to the agency costs that result from the divergence of interest between user (principal), who wants to get a unique product and the hired manufacturer (agent), who may have an incentive to use the solutions that she already has or to create new solutions that could be attractive for a wider range of potential users in the future (von Hippel, 1998).

Another explanation for user innovation is the stickiness of needrelated information, i.e. the incremental expenditure required to transfer the particular unit of information to a specified locus in a form useable by an information seeker (von Hippel, 1994). The higher the cost of transfer is, the stickier the information is. If the information required in the innovation process is sticky, the process (or the particular part of it) will be carried out in the locus of that information. While there is the possibility to "unstick" the information, the manufacturer, who will use this particular information for only one user, has no incentive to engage in this costly process and would rather shift the locus of the innovation process to the user (von Hippel, 1998).

\section{Beyond utilitarian motives - incentives for creating and sharing innovation} While the early user innovation literature focused mostly on users developing products by themselves and for themselves, the advent of collaborative innovation projects, such as open-source software (OSS), has prompted a new wave of research focused on factors driving users not only to create, but also to share innovation (von Hippel \& von Krogh, 2003). However, the phenomenon of innovation sharing has been observed also in other industries and in 
regard to various products (de Jong \& von Hippel, 2009; Franke \& Shah, 2003; Lüthje, 2004; Lüthje, Herstatt \& von Hippel, 2005; Morrison, Roberts \& von Hippel, 2000; Eric von Hippel, 2007). Furthermore, research also shows that firm-users often "freely reveal" what they have developed for in-house use. As long as there is no rivalry between user-innovator and potential adopters, users often decide to voluntarily give up exclusive intellectual property rights to innovation and give access to it to all interested parties.

Motives for innovation creation and sharing include business motives, e.g. enhancement of reputation in the industry, generation of positive network effects or obtaining a cheap source of supply for the innovation (Baldwin \& von Hippel, 2011). Freely revealing their innovation, users also avoid the generally high cost of protecting design information that requires security walls and restricted access or the enforcement of intellectual property rights (transaction costs motives) (Kollock, 1999) Motives for innovation creation and sharing include business motives, e.g. enhancement of reputation in the industry, generation of positive network effects or obtaining a cheap source of supply for the innovation (Baldwin \& von Hippel, 2011). Freely revealing their innovation, users also avoid the generally high cost of protecting design information that requires security walls and restricted access or the enforcement of intellectual property rights (transaction costs motives) (Kollock, 1999).

Lerner and Tirol (2002) try to explain knowledge sharing within open source communities by referring to reputational factors and signalling incentives. Authors argue that the main driver for a programmer to contribute to open source software (OSS) projects is the delayed payoff that such a contribution may generate in the form of future job offers or wage premium. Another group of user innovation drivers relates to the growth in self-esteem and pride that might be the result of innovation process. Kollock (1999) suggests that a person decides to share knowledge because the act creates a sense of efficacy, that is, a sense that they have an impact on the community and, thus, supports their own self-image as an efficacious person. Developing and sharing innovation can also lead to higher peer-recognition and the sense of ownership and control over the innovation process and its product (von Hippel \& von Krogh, 2003).

Finally other researchers point out to hedonic motives for users to voluntarily create and share innovation. The very process of problem-solving can be perceived as an intrinsically rewarding task, it can bring enjoyment from engaging in creative and challenging work and create learning opportunities (Lakhani \& Wolf, 2005; von Hippel \& von Krogh, 2003). User innovators may be also motivated by a willingness to be a part of the so called "gift culture" 
based on trust and altruism, in both its reciprocal and pure version (Hau \& Kim, 2011).

\section{Who is the user-innovator?}

Users are those who directly benefit from created innovation (von Hippel, 2005). It has been long argued that user innovation tends to be concentrated among lead users (Lüthje, 2004; Morrison et al., 2000; Schreier, Oberhauser \& Prügl, 2007), who combine two characteristics: (1) they expect attractive innovation-related benefits from a solution to their needs; (2) they experience needs ahead of the majority of a target market (von Hippel, 1986). Prior research on innovation by lead users indicates that high benefit expectations are often related with the experience of new, stringent needs that are not addressed by existing market offers. With their ability to forecast future demand and their motivation to innovate regardless of market size and uncertainty level, lead users' contributions are most valuable in the early stages of a product life cycle (Chatterji \& Fabrizio, 2012). Other authors argue that lead users also play an important role in the stage that innovation is put to use. They are opinion leaders, who perceive new technologies as less complex and are more ready to adopt them than ordinary users (Schreier et al., 2007). Therefore, tapping lead users for concept and prototype testing, afterlaunch modifications and innovations in function (Harrison \& Waluszewski, 2008) may increase the chances for adoption (see also Douthwaite, Keatinge \& Park, 2001).

However, the innovative performance of individuals is influenced not only by their motivation, but also by their qualifications. Thus it is argued that lead user characteristics in combination with user expertise in a given product field, in terms of use experience and product-related knowledge, are positively associated with the likelihood of user's innovation propensity (Lüthje, 2004). Use experience is the knowledge gained from direct acquaintance (Russell, 1948). Product related knowledge consists of knowhow about the product architecture, the used materials and the applied technologies in the particular product category (Lüthje, 2004). This type of knowledge often comes from a user's professional background or hobbies (Lüthje et al., 2005). User-innovators generally are experts in the field or activity, giving rise to their needs and often have high levels of solution expertise (von Hippel, 2005, p. 74-75).

Studies on Ul focused traditionally on lead users. However over the last decade the interest of not only researchers, but also practitioners, who in search for new sources of innovation and competitive advantage, have started to shift towards ordinary users and their role in innovation processes. For 
instance, Chu and Chan (2009) argue that normal users' feedback may prove to be valuable for the testing and launching stage of new product development. Hyysalo (2009)namely users' adaptations and micro-innovations and their impact on industry development in user-innovation-intensive industries. It complements previous analyses of rodeo and freestyle-kayaking that explore the role of user innovators in industry development, by focusing on different aspects of micro-innovation: (1 suggests that after the product launch, the move from early radical innovation to market expansion depends on a stream of micro-innovations and micro-adaptations that are the domain of normal users.

Ordinary users may prove to be a valuable source of innovation, especially if they are encouraged and supported by manufacturers to participate in the innovation process (Kristensson, Gustafsson \& Archer, 2004). Schreier, Fuchs and Dahl (2012) studied the consumer perception of firms that sell products designed by ordinary users and show that the innovation effect of common user design leads to positive outcomes with respect to purchase intentions, willingness to pay, and willingness to recommend the firm to others. The authors identify four factors that build positive perceptions of common design: (1) the number of consumers; (2) the diversity of their background; (3) the lack of company constraints and (4) the involvement of actual users of the product in the design process. However, even for relatively simple design tasks, the innovation effect of user design depends on consumers' familiarity with user innovation and that common design by users loses its perceived power in case of more complex products and technologies.

\section{What type of innovation do users create?}

Some of the most important and novel commercialized inventions are developed by firm-users for in-house use (Baldwin \& von Hippel, 2011). User firms developed important innovations in oil refining (Enos, 1962), the construction industry (Slaughter, 1993)the users may be in a better position to both identify the exact nature of these problems and to solve them through their own innovations. In a detailed field-based study of the residential construction industry, I find that user-builders, rather than component manufacturers, are the developers of almost all of the innovations $(n=34$, agriculture (Aoki, 2009)plant tissues and genetic sequences in plants and problems this poses for global food supply and agriculture. The article then goes on to analyze recent treaties such as the 2001 International Treaty on Plant Genetic Resources for Food and Agriculture (ITPGR, in chemical production processes (Freeman, 1968), in machine tools (Rosenberg, 1976), scientific instruments (von Hippel \& Finkelstein, 1979) and information 
systems (Nambisan, Agarwal \& Tanniru, 1999). A similar tendency is observed in the case of consumer products. For instance, users played a central role in the development of sports equipment (Franke \& Shah, 2003; Hienerth et al., 2006), cars, home-used tools and software (Flowers, von Hippel, de Jong \& Sinozic, 2010). User innovation also plays an important role in service industries. For example Oliveira and von Hippel (2011) find that 55\% and $44 \%$ of today's computerized commercial and retail banking services respectively, were first developed and implemented by users.

Another type of innovation developed by users is innovation in function (Baldwin, Hienerth \& von Hippel, 2006), that is the introduction of a new use for a given technological object. Some examples of user-driven innovation in this area are free-style skiers, surgeons developing new procedures, teachers using games for educational purposes or DJs using turntables as musical instruments. Faulkner and Runde (2009) argue that users dominate manufacturers as innovators in function and that this type of user-innovation inspires manufacturers to implement changes in form.

As far as newness of user innovation is concerned the literature provides evidence that users develop both radical and incremental changes. Lead users do a lot of commercially significant process development and product modification in many fields (Flowers et al., 2010). The performance level of these user developments can be explained by the fact that lead users are ahead of the trend in terms of demand and have significant incentives to solve a given problem (Jeppesen \& Frederiksen, 2006). While lead users' ideas are more radical, the ideas from ordinary users tend to be more incremental (Hyysalo, 2009)namely users' adaptations and micro-innovations and their impact on industry development in user-innovation-intensive industries. It complements previous analyses of rodeo and freestyle-kayaking that explore the role of user innovators in industry development, by focusing on different aspects of micro-innovation: (1.

However, newness of user innovations depends also on the field in which these new solutions are implemented. For instance Lüthje et al. (2005) report that most of the innovations by lead users in mountain biking can be characterized as "moderate improvements", which is generally the predominant innovation pattern in the field in question.

\section{How do users innovate?}

The results of the literature review enabled the author to identify two sets of themes related to the "how" question. The first divides UI into two contrasting models: user-centric and firm centric. The user-centric model, originating from the earliest research on $\mathrm{UI}$, focuses mainly on firms and 
individuals that directly benefit from innovation (von Hippel, 1988), using it to address their own needs. The firm-centric model has developed as a producers' response to the growing awareness of users' innovation activities. It is primarily concerned with accessing and leveraging users as a source of external knowledge that could improve a firm's internal innovation processes and its economic performance (Bogers et al., 2010). Thus, it would be more appropriate to relate to this model as user-driven innovation rather than user innovation per se, which is to be discussed in the next section focused on major weaknesses of the UI literature. The second set of themes relates to the locus of innovation created by users. Innovation can be a product of either individual or collaborative effort. While in the first case only one user (firm or consumer) is engaged in the innovation process, in the second, innovation is created by a community of users.

The combination of these two identified sets of themes leads to a fourfold classification of UI models: 1 . single user innovation; 2 . user community innovation; 3. mass-customized innovation; 4. firm-hosted community innovation (see Figure 1 below).

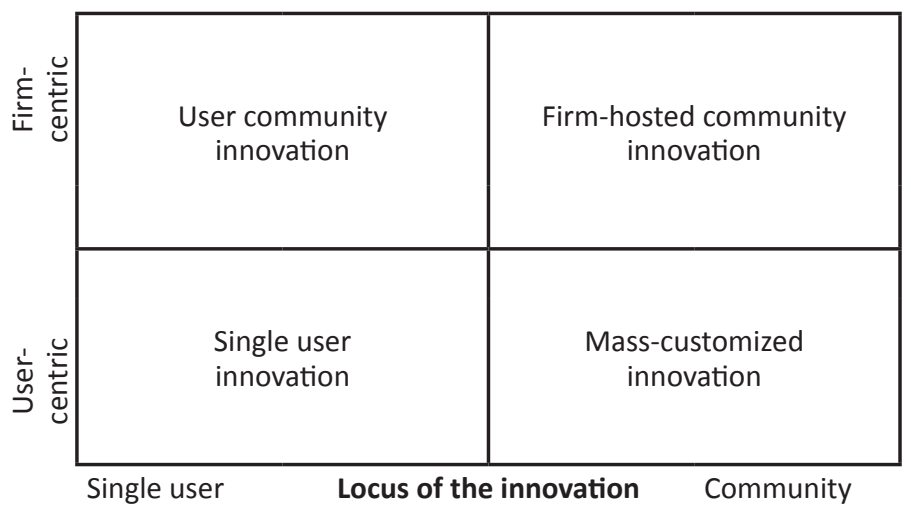

Figure 1. User innovation models

\section{Single user innovation}

A single user innovator is a single firm or individual that creates an innovation in order to use it (Baldwin \& von Hippel, 2011). Single users engage in the innovation process, when the benefits from using the innovation are higher than the costs of creating it, and these include transaction, design and production costs. The results of the literature review indicate that user innovators are generally not interested in commercializing their innovation or rarely seek to assert exclusive rights over it (Lüthje, 2004). Thus they often 
incur no transaction costs and while deciding whether to create innovation or not, they take only design and production costs into account (Baldwin \& von Hippel, 2011). As users rely primarily on the local need and solution information that they already have "in stock" to develop innovations (Lüthje et al., 2005), the level of design costs are at large determined by the level of the innovator's use experience and technical capabilities. While production costs in the case of digitized products goods are zero, in other industries specialized manufacturers maintain their advantage over users in respect to the cost of production. Nevertheless technological development, especially in computerization and 3D printing, increases users' production capabilities.

For some users, innovation ideas and efforts become the starting point for their businesses. User entrepreneurship occurs in vastly different industries (Chandra \& Leenders, 2012; Haefliger, Jäger \& Von Krogh, 2010; Shah, Smith \& Reedy, 2012; Shah \& Tripsas, 2007). Shah and Tripsas (2007) propose that user-entrepreneurship is more likely to dominate classic sources of entrepreneurship under four conditions: (1) when the use of a particular product provides enjoyment; (2) when users have relatively low opportunity cost; (3) when the industry is characterized by niche markets with a high variety in demand; (4) when the market for the product is highly uncertain. The process of commercialization of user innovation may be divided into four stages (Baldwin et al., 2006). First, one or more users recognize a new set of design possibilities and begin to innovate in order to satisfy their own unique and unserved needs. They then obtain feedback from other users, either unintentionally, simply by using the innovation or intentionally, or by freely revealing innovation-related information. Signals from the community allow them to improve the solution and to notice its commercial potential. In the next step user-manufacturers emerge, using high variable cost/ lowcapital production methods. Their advantage over established manufacturers is threefold: (1) they have already made the investment to design the product; (2) they have already established relationships with potential buyers and can use low-cost, word-of-mouth marketing techniques; (3) by setting up prototyping facilities they have already invested in small amount of manufacturing capital. In the last phase user innovation slows, the market stabilizes enough for established manufacturers with high production capital investment and low variable costs to enter.

\section{User community innovation}

Collaborative user innovation is created in the process of cooperation between many users, who first seek to develop a solution that would address their needs and then freely reveal it for anyone to use. A number of studies (Franke 
\& Shah, 2003; von Hippel \& von Krogh, 2003) suggest that collaborating users, who join peer-to-peer special-interest communities (both online and offline), may yield new or modify existing products and services in different fields. There are two main driving forces for user community innovation: transition to increasingly digitized and modularized design and production practices, and the development of low-cost, Internet-based communication (Baldwin \& von Hippel, 2011). In a modular system a given component is dependent on the characteristics of other components within its subsystem (module), but is independent from parts outside that subsystem (Baldwin \& Clark, 2000). Modularity increases the flexibility of configuration and allows independent and dispersed contributors to design separate modules in parallel. However, user innovators, particularly those working on digital goods, cooperate not only across modules but also within modules. Colfer (2009) argues that they achieve coordination through the so-called "actionable transparency". The emerging artefacts can be easily understood (are transparent) by other contributors and allow real-time iteration due to rapid generate-test cycles (are actionable). Actionable transparency would not be possible without broadband, peer-to-peer and real-time communication.

Since collaborating users must communicate with one another rapidly and repeatedly, communication costs are the most critical condition for this type of user innovation (Baldwin \& von Hippel, 2011). For users engaging in an innovative community, costs of design are marginal as they are divided into a number of co-creators. Additionally users do not face any transaction costs, as all solutions are freely revealed (ibidem). However, due to production costs the applicability of the collaborative innovation model is still limited mostly to information goods (von Hippel, 2007).

\section{Mass-customized innovation}

Not all users with unique needs have technical capabilities to design and produce innovation for themselves. They can either settle for a mass product or design it with the help of standard toolkits provided by the manufacturer of mass-customized products and services (von Hippel, 1998). Mass customization aims at the production of products and services with enough variety and customization that nearly everyone finds exactly what they want at prices comparable with standard offerings (Pine, 1993). Toolkits for user innovation used in this process are coordinated sets of "user-friendly" design tools that enable users (especially those ordinary ones) to solve need-related problems and develop innovations for themselves (von Hippel \& Katz, 2002).

Instead of trying to guess what users want, companies may simply give them the opportunity to construct their own products (Desouza, Awazu \& 
Ramaprasad, 2007). The economic value of self-designed products has been attributed to the utilitarian (product of perfect fit) (Franke, Keinz \& Steger, 2009)researchers have paid increasing attention to the marketing strategy of customization. A key assumption is that customized products create higher benefits for customers than standard products because they deliver a closer preference fit. The prerequisite for this effect is the ability to obtain precise information on what customers actually want. But are customers able to specify their preferences that precisely? Several theoretical arguments raise doubts about this, implicitly challenging the value of customization. The authors conduct two studies in which they find that products customized on the basis of expressed preferences bring about significantly higher benefits for customers in terms of willingness to pay, purchase intention, and attitude toward the product than standard products. The benefit gain is higher if customers have ( 1 , hedonic (enjoyment from the creative activity) (Franke \& Piller, 2004) and self-esteem ("I designed it myself" effect) consumer benefits ( (Franke, Schreier \& Kaiser, 2009). Additionally it has been found that custom designs created by users are also attractive to non-designers (Franke \& Piller, 2004; Schreier et al., 2012). Toolkits may also "serve as a crèche for interested but inexperienced users who could evolve into leading-edge users over time" (Prügl \& Schreier, 2006).

Despite its benefits, mass customization generates two types of costs for the customer. Firstly, there is a direct cost in the form of a price premium that customer needs to pay for a custom product. Secondly, customers may perceive indirect, cognitive costs related with the risk of being involved in co-creation (Franke \& Piller, 2003). Co-design activities can result in the perception of extended complexity, additional time and effort during the buying process, and may lead to "mass confusion" (Huffman \& Kahn, 1998). There are three potential sources of this phenomenon: (1) burden of choice; (2) matching needs with product specifications; (3) uncertainty related to the behaviour of the supplier.

Concluding, a user will decide to innovate with toolkits provided by the producer when: the production costs are high, so that the consumer is not able to manufacture the self-designed product themselves; and the price of the customized product, and design and communications costs, are relatively low compared to the utilitarian, hedonic and self-esteem benefits. While communications costs, as has already been mentioned, in the era of ICT are low, the design costs are mostly determined by the skills of the user and the level of toolkits' "user-friendliness". 


\section{Firm-hosted community innovation}

Firm-hosted communities generate interaction and co-operation between users and the company, and between users themselves. Forms of such engagement include conventional lead user method and online user communities. The lead user method accelerates the identification of new product or service concepts, and decreases the risks and costs related with these activities (von Hippel, 2005). Additionally, some authors believe (Piller \& Walcher, 2006) that the conventional lead user approach can significantly benefit from the utilization of broader online user communities. Engaging user networks can be used to conduct broad, preliminary screening for innovation opportunities that can be developed later on in more specific challenges or during classical lead user workshops. This form of co-operation with users supports the lead users' selection process, allows a deepening of the relationship with other customers, and identifies opportunities for some incremental changes that would satisfy current needs.

Marchi, Giachetti and de Gennaro (2011) distinguish three main characteristics of lead users within firm-hosted communities: (1) a user's willingness to collaborate in the innovation process; (2) their product knowledge; and (3) a strategic alignment with the brand identity. Consumers engage in firm-hosted communities because they are intrinsically interested in the innovation activity and are responsive to firm recognition (Jeppesen \& Frederiksen, 2006), but also for monetary compensation (Füller, 2006). Hienerth, Keinz and Lettl (2011) argue that the successful implementation of user-centric business models requires a comprehensive approach encompassing not only effective incentive systems, but also an appropriate social software design, a transparent intellectual property policy, and policies, strategies and structures for effective learning processes and employee empowerment.

Table 1 contains a summary of the literature review findings discussed above.

User innovation is a rich concept, encompassing different forms of activities, different actors and relations between them. The results of the systemic literature review in regard to the "how" question reveal that there are four major research streams on user innovation constructed around different models of UI. Each of the identified streams provides different answers to the remaining three research questions and is determined by different critical conditions. 
Table 1. User Innovation - main research streams

\begin{tabular}{|c|c|c|c|c|}
\hline \multicolumn{5}{|c|}{ HOW? } \\
\hline & $\begin{array}{l}\text { Single user } \\
\text { innovation }\end{array}$ & $\begin{array}{l}\text { User community } \\
\text { innovation }\end{array}$ & $\begin{array}{l}\text { Mass-customized } \\
\text { innovation }\end{array}$ & $\begin{array}{l}\text { Firm-hosted } \\
\text { community innovation }\end{array}$ \\
\hline 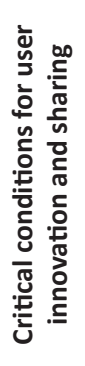 & $\begin{array}{l}\text { Design and } \\
\text { production } \\
\text { costs lower than } \\
\text { benefits }\end{array}$ & $\begin{array}{l}\text { - Communication and } \\
\text { production costs } \\
\text { lower than benefits } \\
\text { - Low rivalry } \\
\text { - Transaction costs } \\
\text { higher than } \\
\text { benefits from } \\
\text { commercialization }\end{array}$ & $\begin{array}{l}\text { - Price, } \\
\text { design and } \\
\text { communication } \\
\text { costs lower } \\
\text { than benefits } \\
\text { - Production } \\
\text { costs higher } \\
\text { than benefits }\end{array}$ & $\begin{array}{l}\text { - Communication } \\
\text { costs lower than } \\
\text { benefits } \\
\text { - Production costs } \\
\text { higher than benefits } \\
\text { - Low rivalry (user-to- } \\
\text { user; firm-to-user) } \\
\text { - Transaction costs } \\
\text { higher than } \\
\text { benefits from } \\
\text { commercialization }\end{array}$ \\
\hline$\stackrel{2}{\grave{1}}$ & $\begin{array}{l}\text { - Utilitarian } \\
\text { motives } \\
\text { - Hedonic motives } \\
\text { - Self-esteem } \\
\text { motives } \\
\text { - (“I designed it } \\
\text { myself” effect) }\end{array}$ & $\begin{array}{l}\text { - Utilitarian motives } \\
\text { - Business motives } \\
\text { - Transaction costs } \\
\text { motives } \\
\text { - Signalling motives } \\
\text { - Hedonic motives } \\
\text { - Gift culture motives } \\
\text { - Self-esteem motives }\end{array}$ & $\begin{array}{l}\text { - Utilitarian } \\
\text { motives } \\
\text { - Hedonic motives } \\
\text { - Self-esteem } \\
\text { motives } \\
\text { - (“I designed it } \\
\text { myself” effect) }\end{array}$ & $\begin{array}{l}\text { - Utilitarian motives } \\
\text { - Hedonic motives } \\
\text { - Gift culture } \\
\text { motives } \\
\text { - Self-esteem } \\
\text { motives } \\
\text { - (incl. firm } \\
\text { recognition) } \\
\text { - Financial motives }\end{array}$ \\
\hline مْ & $\begin{array}{l}\text { - Firms } \\
\text { - Individuals } \\
\text { - Lead users } \\
\text { - Ordinary users }\end{array}$ & $\begin{array}{l}\text { - } \text { Firms } \\
\text { - Individuals } \\
\text { (prevalence) } \\
\text { - Lead users } \\
\text { - Ordinary users }\end{array}$ & $\begin{array}{l}\text { - Ordinary users } \\
\text { - (crèche for lead } \\
\text { users) }\end{array}$ & $\begin{array}{l}\text { - Lead users } \\
\text { - Ordinary users }\end{array}$ \\
\hline$\frac{\mathfrak{E}}{\stackrel{1}{1}}$ & $\begin{array}{l}\text { - Radical - lead } \\
\text { users } \\
\text { - Incremental - } \\
\text { ordinary users } \\
\text { (after-launch } \\
\text { micro- } \\
\text { innovation) } \\
\text { - Product (mainly } \\
\text { inf. goods) } \\
\text { - Service } \\
\text { - Process } \\
\text { - Function }\end{array}$ & $\begin{array}{l}\text { - Radical - lead users } \\
\text { - Incremental - } \\
\text { ordinary users } \\
\text { (after-launch micro- } \\
\text { innovation) }\end{array}$ & $\begin{array}{l}\text { - } \\
\text { - Product } \\
\text { - Service }\end{array}$ & $\begin{array}{l}\text { - Radical } \\
\text { - Incremental } \\
\text { - (screening; testing; } \\
\text { after-launch micro- } \\
\text { innovation) }\end{array}$ \\
\hline
\end{tabular}

\section{CRITIQUE AND PERSPECTIVES FOR FUTURE RESEARCH}

The following section presents major weaknesses of previous studies on UI and the identified areas for future queries. Table 2 presents the research results applicable both to the entire field as well as to specific research 
streams derived from the literature review. The table is followed by a thorough discussion of the results.

Table 2. User Innovation - weaknesses and future research directions

\begin{tabular}{|c|c|c|c|c|}
\hline & \multicolumn{4}{|c|}{ Problems for future research } \\
\hline $\begin{array}{l}\frac{\pi}{0} \\
\frac{c}{d}\end{array}$ & \multicolumn{4}{|c|}{$\begin{array}{l}\text { - Definitional clarity: need for clear distinction between user } \\
\text { and user-driven innovation } \\
\text { - Large-scale research to measure the impact and validate propositions } \\
\text { - Cultural context } \\
\text { - User innovation and social welfare } \\
\text { - Policy implications } \\
\text { - Who, What, When? }\end{array}$} \\
\hline & $\begin{array}{l}\text { Single user } \\
\text { innovation }\end{array}$ & $\begin{array}{l}\text { User } \\
\text { community } \\
\text { innovation }\end{array}$ & $\begin{array}{l}\text { Mass-customized } \\
\text { innovation }\end{array}$ & $\begin{array}{l}\text { Firm-hosted } \\
\text { community } \\
\text { innovation }\end{array}$ \\
\hline 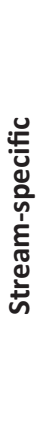 & $\begin{array}{l}\text { User } \\
\text { entrepreneurship } \\
\text { (prevalence, } \\
\text { determinants, } \\
\text { success factors, } \\
\text { community } \\
\text { dynamics) }\end{array}$ & $\begin{array}{l}\text { - Collective } \\
\text { intelligence } \\
\text { or stupidity }\end{array}$ & $\begin{array}{l}\text { - Strategic } \\
\text { capabilities } \\
\text { required for } \\
\text { success } \\
\text { - External factors } \\
\text { for success } \\
\text { (national } \\
\text { cultures) } \\
\text { - Mass confusion } \\
\text { - when does it } \\
\text { occur and how } \\
\text { to minimize its } \\
\text { risks? }\end{array}$ & $\begin{array}{l}\text { - Collective } \\
\text { intelligence or } \\
\text { stupidity } \\
\text { - Dynamics and life } \\
\text { cycle of firm-hosted } \\
\text { communities } \\
\text { - User roles, position, } \\
\text { leadership } \\
\text { - User motivation } \\
\text { (including material } \\
\text { rewards) } \\
\text { - Firm-user conflicts }\end{array}$ \\
\hline
\end{tabular}

\section{Definitional chaos}

Most of the analysed literature on UI does not build on the traditional distinction between innovation and invention (Schumpeter, 1934), focusing much more on the idea generation and design part of the innovation process. Innovation is understood as a "practical implementation of an idea into a new device or process" (Schilling, 2013, p. 18.). As it has been discussed in this paper, users provide more than merely ideas for new products - they help to identify needs, define product specifications, create design and even produce and distribute innovation independently from manufacturers. Bogers et al. (2010) argue, however, that it would be easier to compare studies if concepts related to user innovation are more explicitly defined with a distinction between idea generation, implementation and diffusion. Thus future studies need to make a clear distinction between user innovation, that is innovation 
invented and actually implemented (at least for in-house use) by users and users only, and user-driven innovation - the concept, in which users are engaged in one of the phases of the process, for instance as a source of ideas or new solution testers. The proposed typology of UI models, and more specifically the user-centric and firm-centric perspective used in it, may serve as a tool for such a distinction.

\section{Measuring the prevalence and impact of UI}

With a few exceptions (Chatterji, 2012; de Jong \& von Hippel, 2009; Flowers et al., 2010; Schreier, 2012) the analysed research field is largely based on small sample studies that merely demonstrate the phenomenon without measuring its effect. Lack of large-scale empirical research presents the major weakness of UI literature and probably the biggest challenge for scholars exploring this subject. Although literature provides clear evidence on the existence of user innovation in various industries, it does not show in what industries it is prevalent and how it affects industry dynamics. Due to the rise of low cost "user-manufacturing" technologies, especially 3D printing, the question of a user's impact on industry dynamics becomes even more important. Another field for further investigation relates to the problem of how universal $\mathrm{UI}$ is across nations. Future studies could explore cultural (Hofstede, 1984) and institutional (DiMaggio \& Powell, 1983) drivers for user innovativeness.

In contrast to the formal R\&D activities of firms, innovative efforts of users, especially those of individuals and communities are not illustrated in any official statistics. Much of user innovation results in minor and subtle changes that are extremely difficult to trace and measure. Yet, some authors (Henkel \& von Hippel, 2004) suspect that their cumulative economic impact might be tremendous. Future research could explore how important it is for social welfare, and to what extent and in what way it should be integrated into policy and law making (Fisher III, 2010).

Additionally, considering the impact that the level of entrepreneurship has on economic growth, further research on user-entrepreneurship is highly needed. The literature on this topic would greatly benefit from large-scale studies that could validate models presented in the literature review section of this article, measure their prevalence, identify determinants (e.g. types of product, users' characteristics, cultural dimensions) and provide insights on key success and failure factors. 


\section{Who, What, When?}

As has been discussed in the previous section there is strong consensus among researchers that innovation is the domain not only of lead, but also ordinary users. The literature is also consistent in regard to the consequences of users' innovative behaviour - there is empirical evidence that users can create both radical (mostly lead users) and incremental (mostly ordinary users) innovation in product, process, service and function. However, again, since large-scale studies on UI are scarce, the literature does not provide the answer to the "when" question. What are the contingency factors influencing innovativeness of a particular group of users? For example Magnusson and Kristensson (2010) provide empirical evidence that in order to provide innovative ideas, ordinary users must have both a high level of contextual use experience and not have "too much" technical knowledge that, in fact, restricts the ideation process. This study was, however, limited to innovation in technology-based services and its results haven't been verified with regard to other products or services. What type of user-innovators and what type of innovation are dominant in particular industries and economies (assuming that national cultures and institutional environment have an impact on user innovativeness)?

Furthermore, dichotomous classification of innovation into radical and incremental is, according to some scholars (Henderson \& Clark, 1990; Tushman, Anderson \& O'Reilly, 1997), insufficient to capture the current trends, too general, and conceptually ineffective. Thus, user innovation literature would gain from some additional insights on types of changes that are created by users, whether they are incremental or radical in respect to market and technology, architectural, modular or generational. Their impact on firm performance and on industry dynamics is different, and various types of innovation might be the result of the activity of different users.

\section{Exploring mass customization}

Another research area that requires further deliberation refers to mass customization. First, as it has been emphasized in the literature review section, mass customization generates many potential benefits for manufacturers seeking to address heterogeneous demands. However, it is still rather a niche strategy implemented mostly by start-ups entering mature markets. While there is growing interest of managers and academia in this approach to product development, there are also a growing number of companies who have tried to implement it and failed. Therefore, the literature would benefit 
from further exploration on success and failure factors of mass customization as a single strategy or as a part of a holistic user-centric approach to innovation. Future studies should focus more on the strategic capabilities required for the introduction of mass customization strategy, as well as external determinants of success, especially those related to differences in national cultures.

Second, some authors have emphasized the downside of mass customization related to the complexity that a user faces while designing the product and argued that proper design of toolkits for UI, personalization features and fostering community co-design may decrease the risk of mass confusion (Piller, Koch, Möslein \& Schubert, 2003; Piller, Schubert, Koch \& Möslein, 2005)research on the role of the customer within the co- design process is rare. However, customers face new uncertainties and risks when purchasing a customized good. We discuss these risks and provide a new approach to address these problems based on personalization and collaboration. We will analyze how personalization of the co-design process and collaboration of users within communities can render (mass. However, most of the academic papers exploring this phenomenon are based either on literature reviews or case studies. Thus there is a need for a broad-scale quantitative study of consumer choice and buying behaviour during the mass customization process. Research on sources, but also moderating and mediating factors (in particular product type and user characteristics) of mass confusion is encouraged.

\section{Firm-community relationships}

As the locus of innovation is intensively shifting from dyadic relationships towards ecosystems, networks and communities (Vanhaverbeke, West \& Chesbrough, 2014) there is growing demand for further research on mechanisms governing the collaboration within firm-hosted innovation communities. For instance, it would be interesting to study the dynamics and life cycle of such communities. Important insights could be drawn from exploration on leadership processes, user roles and positions in the communities (Dahlander \& Frederiksen, 2012).

Furthermore, as has been highlighted in the previous section, there is strong evidence in the literature that users are willing to freely reveal innovation-related information and share their solutions within their community. It has also been observed that some users are eager to share innovation with companies. While in the first case the revealed information becomes a public good, in the second it is acquired by the firm, utilized in its innovation process, integrated into commercial product and sold. Although some authors have already discussed factors driving users to contribute to 
firm-hosted communities, many questions still seemed to be unanswered. As the gift culture of user communities is based on reciprocity and trust, what is it that company can offer users in return? What are the limits of users' "generosity"? Is "fun from design", identification with the brand and interaction with other members, really enough to attract and keep the most talented and active users within the community?

In relation to the questions concerning user motivation it would be interesting to explore further the impact of material rewards on the firmuser relationship. Füller (2006) found that monetary compensation has a negative impact on further participation in firm-hosted co-creation projects and a positive impact on participation frequency, and it becomes important for users willing to spend more time and effort on the task. But what is the impact of material rewards on the quality of submissions? What type of material rewards motivate best? Do they serve as motivational factors or merely hygiene ones (Herzberg, 1964)? What user characteristics determine the motivational power of particular rewards?

Another fertile ground for future studies relates to conflicts between companies and user communities. Users may feel dissatisfied with the cocreation process and feel exploited by the firm. Conflicts may occur also as a result of miscommunication or a firm's controversial actions in areas not related directly to the project, but still important for the community (e.g. ethical scandals). What are the effects of such conflicts? How do they evolve? What are the strategies to manage them? Valuable insights could be gained here from the still scarce research on failures in managing co-creation with users.

\section{Collective intelligence or collective stupidity?}

Collaborative innovation projects, both those initiated by firms and by users only, are based on the collective intelligence assumption. It has been argued (Buecheler, Sieg, Füchslin \& Pfeifer, 2010; Mollick \& Nanda, 2015; Surowiecki, 2004; Wagner \& Vinaimont, 2010) that in contrast to groups, collectives are resistant to reasoning biases, such as groupthink (Janis, 1982) and herd behaviour (Banerjee, 1992), and thus outperform teams of experts in decisionmaking. There is however growing evidence that this is not always the case. Breitsohl, Wilcox-Jones and Harris (2015) investigate customers' tendency to conform when making decisions in a financial online community and support the applicability of groupthink theory in an online context. Muchnik, Aral and Taylor (2013) designed a large-scale randomized experiment on a social news aggregation Web site and found that prior ratings created significant bias in individual rating behaviour. Another experimental evidence (Lorenz, Rauhut, Schweitzer \& Helbing, 2010) shows that even mild social influence 
can undermine the collective intelligence in simple estimation tasks. Knowledge about responses of other users narrows the diversity of opinions and undermines the wisdom of crowd through three mechanisms: (1) "social influence effect" diminishes the diversity of the crowd; (2) "range reduction effect" moves the position of the truth to peripheral regions; (3) "confidence effect" boosts individuals' confidence about providing the right answer.

Results of these studies have direct implications for firm-hosted communities, especially those using peer-rating mechanism. As Noble (2012) argues, many crowdsourcing initiatives reward answers that agree with the masses, disregarding minority voices. Surowiecki (2004) identifies three requirements for collective wisdom to emerge: diversity, decentralization of opinion, and independence. As meeting these conditions becomes one of the main challenges in managing online communities, there is a growing need for research exploring decision biases in collaborative environments.

\section{CONCLUSION}

Due to the near-omnipresence of broadband Internet, decreasing costs of hardware and software, and increasing access to information, users are becoming more and more sophisticated. Innovation is no longer limited to companies with large R\&D budgets and starts to be dispersed among many creative and entrepreneurial individuals. User innovation is a concept that has recently attracted a lot of attention, both in practice and in academia. Since the early works of von Hippel over four decades ago, we have learned a lot about the role that users play in innovation, about their motivation, characteristics and innovation capabilities. Nevertheless, much more research is needed.

This paper provides a comprehensive review of literature that investigates user innovation, identifies some of the weaknesses of past research and suggests possible future research directions in the area. The results of the analysis enabled the author to distinguish four models of UI - single user innovation, user community innovation, mass-customized innovation and firm-hosted community innovation - that define the main research streams and provide conceptual tool for further studies in this rich and chaotically defined area. Findings presented in the paper indicate that user-innovators are driven by various motives ranging from utilitarian to hedonic and even altruistic ones. What is more, while researchers have traditionally associated UI with lead users providing radical solutions, there is also some empirical evidence for innovative activity, although mostly of an incremental character, of ordinary users. 
The results of the conducted analysis indicate that areas and topics for further exploration include user entrepreneurship, the phenomenon of mass confusion and innovation in user and firm-hosted communities, and more specifically the problems of governance, conflicts and collective intelligence in such communities. The major shortcoming of the previous studies, identified in this review, is the lack of large sample research that could provide validation of the discussed concept, especially the impact of $\mathrm{UI}$ and user entrepreneurship on industry dynamics and social welfare. We still know little about what types of users are typical innovators in particular industries, what types of innovation they create, and how their innovativeness can be stimulated. Thus future research should most of all focus on quantitative studies involving large samples in various industries and countries, not only in the US and Europe but also in Asia, to determine the frequency and importance of various practices and context factors.

\section{References}

Aoki, K. (2009). Free seeds, not free beer: Participatory plant breeding, open source seeds, and acknowledging user innovation in agriculture. Fordham Law Review, 77(5), 2275-310.

Baldwin, C., Hienerth, C., \& von Hippel, E. (2006). How user innovations become commercial products: A theoretical investigation and case study. Research Policy, 35(9), 1291-1313.

Baldwin, C., \& von Hippel, E. (2011). Modeling a paradigm shift: From producer innovation to user and open collaborative innovation. Organization Science, 22(6), 1399-1417.

Baldwin, C. Y., \& Clark, K. B. (2000). Design Rules. Cambridge, MA: MIT Press. Banerjee, A. V. (1992). A simple model of herd behavior. The Quartely Journal of Economics, 107(3), 797-817.

Bogers, M., Afuah, A., \& Bastian, B. (2010). Users as innovators: A review, critique, and future research directions. Journal of Management, 36(4), 857-875.

Breitsohl, J., Wilcox-Jones, J. P., \& Harris, I. (2015). Groupthink 2.0: An empirical analysis of customers' conformity-seeking in online communities. Journal of Customer Behaviour, 14(2), 87-106.

Buecheler, T., Sieg, J. H., Füchslin, R. M., \& Pfeifer, R. (2010). Crowdsourcing , open innovation and collective intelligence in the scientific method: A research agenda and operational framework why crowdsourcing in the scientific method. Alife XII Conference, Odense, Denmark, 679-686.

Chandra, Y., \& Leenders, M. A. A. M. (2012). User innovation and entrepreneurship in the virtual world: A study of second life residents. Technovation, 32(7-8), 464-476.

Chatterji, A. K., \& Fabrizio, K. (2012). How do product users influence corporate invention? Organization Science, 23(4), 971-987. 
Chesbrough, H., \& Bogers, M. (2014). Explicating open innovation : Clarifying an emerging paradigm for understanding innovation keywords. In $\mathrm{H}$. Chesbrough, W. Vanhaverbeke, \& J. West (Eds.), New Frontiers in Open Innovation (pp. 1-37). Oxford: Oxford University Press.

Chu, K.-M., \& Chan, H.-C. (2009). Community based innovation: Its antecedents and its impact on innovation success. Internet Research, 19(5), 496-516.

Colfer, L. J. (2009). Decoupling Product Architecture from Organizational Structure: When and How Organizations "Break the Mirror" unpublished manuscript (September).

Dahlander, L., \& Frederiksen, L. (2012). The core and cosmopolitans: A relational view of innovation in user communities. Organization Science, 23(4), 988-1007.

Dahlander, L., \& Gann, D. M. (2010). How open is innovation? Research Policy, 39(6), 699-709.

de Jong, J. P. J., \& von Hippel, E. (2009). Transfers of user process innovations to process equipment producers: A study of Dutch high-tech firms. Research Policy, 38(7), 1181-1191.

Desouza, K. C., Awazu, Y., \& Ramaprasad, A. (2007). Modifications and innovations to technology artifacts. Technovation, 27(4), 204-220.

DiMaggio, P. J., \& Powell, W. W. (1983). The iron cage revisited: Institutional isomorphism and collective rationality in organizational fields. American Sociological Review, 48(2), 147-160.

Douthwaite, B., Keatinge, J. D. H., \& Park, J. R. (2001). Why promising technologies fail: The neglected role of user innovation during adoption. Research Policy, 30(5), 819-836.

Enos, J. E. (1962). Invention and innovation in the petroleum refining industry. In The Rate and Direction of Inventive Activity: Economic and Social Factors (pp. 199-322). Universities-National Bureau Committee for Economic Research, Committee on Economic Growth of the Social Science Research Council, Princton University Press.

Faulkner, P., \& Runde, J. (2009). On the identity of technological objects and user innovations in function. Academy of Management Review, 34(3), 442-462.

Fisher III, W. W. (2010). The implications for law of user innovation. Minnesota Law Review, 94(5), 1417-1477.

Flowers, S., von Hippel, E., de Jong, J. P. J., \& Sinozic, T. (2010). Measuring User Innovation in the UK. The Importance of Product Creation by Users. London: NESTA.

Franke, N., Keinz, P., \& Steger, C. J. (2009). Testing the value of customization: When do customers really prefer products tailored to their preferences? Journal of Marketing, 73(5), 103-121.

Franke, N., \& Piller, F. T. (2003). Key research issues in user interaction with configuration toolkits in a mass customization system. International Journal of Technology Management, 26(5), 578-599. 
Franke, N., \& Piller, F. T. (2004). Value creation by toolkits for user innovation and design: The case of the watch market. Journal of Product Innovation Management, 21(6), 401-415.

Franke, N., Schreier, M., \& Kaiser, U. (2009). The "I designed it myself" effect in mass customization. Management Science, 56(1), 125-140.

Franke, N., \& Shah, S. (2003). How communities support innovative activities: An exploration of assistance and sharing among end-users. Research Policy, 32(1), 157-178.

Franke, N., \& von Hippel, E. (2003). Satisfying heterogeneous user needs via innovation toolkits: The case of Apache Security Softwar. Research Policy, 32(7), 1199-1215.

Freeman, C. (1968). Chemical process plant: Innovation and the world market. National Institute Economic Review, 45(1), 29-51.

Füller, J. (2006). Why consumers engage in virtual new product developments initiated by producers. Advances in Consumer Research, 33, 639-646.

Haefliger, S., Jäger, P., \& Von Krogh, G. (2010). Under the radar: Industry entry by user entrepreneurs. Research Policy, 39(9), 1198-1213.

Harrison, D., \& Waluszewski, A. (2008). The development of a user network as a way to re-launch an unwanted product. Research Policy, 37(1), 115-130.

Hau, Y. S., \& Kim, Y.-G. (2011). Why would online garners share their innovationconducive knowledge in the online game user community? Integrating individual motivations and social capital perspectives. Computers in Human Behavior, 27(2), 956-970.

Henderson, R. M., \& Clark, K. B. (1990). Architectural innovation: The Reconfiguration of existing product technologies and the failure of established firms. Administrative Science Quarterly, 35(1), 9-30.

Henkel, J., \& von Hippel, E. (2004). Welfare implications of user innovation. The Journal of Technology Transfer, 30(1-2), 73-87.

Herzberg, F. (1964). The motivation-hygiene concept and problems of manpower. Personnel Administrator, 27(1), 3-7.

Hienerth, C., Baldwin, C., \& von Hippel, E. (2006). How user innovations become commercial products. a theoretical investigation and case study. MIT Sloan Research Paper, 4572-6.

Hienerth, C., Keinz, P., \& Lettl, C. (2011). Exploring the nature and implementation process of user-centric business models. Long Range Planning, 44(5-6), 344-374.

Hofstede, G. (1984). Culture's Consequences: International Differences in Work-Related Values. London: Sage Publications.

Hollander, S. (1965). The Sources of Increased Efficiency: A Study of DuPont Rayon Plants. Cambridge MA: MIT Press.

Huffman, C., \& Kahn, B. E. (1998). Variety for sale: Mass customization or mass confusion? Journal of Retailing, 74(4), 491-513.

Huizingh, E. K. R. E. (2011). Open innovation: State of the art and future perspectives. Technovation, 31(1), 2-9. 
Hyysalo, S. (2009). User innovation and everyday practices: Micro-innovation in sports industry development. R\&D Management, 39(3), 247-258.

Janis. (1982). Groupthink. Boston: Houghton Mifflin.

Jeppesen, L. B., \& Frederiksen, L. (2006). Why do users contribute to firmhosted user communities? The case of computer-controlled music instruments. Organization Science, 17(1), 45-63.

Kollock, P. (1999). The economies of online cooperation: Gift exchange and public goods in cyberspace. Communities in Cyberspace, (Simon 1996), 1-19.

Kristensson, P., Gustafsson, A., \& Archer, T. (2004). Harnessing the creative potential among users. Journal of Product Innovation Management, 21(1), 4-14.

Lakhani, K. R., \& Panetta, J. A. (2007). The principles of distributed innovation. Innovations: Technology, Governance, Globalization, 2(3), 97-112.

Lakhani, K. R., \& Wolf, R. G. (2005). Why hackers do what they do: Understanding motivation and effort in free / open source software projects. In J. Feller, B.

Fitzgerald, S. Hissam, \& K. R. Lakhani (Eds.), Perspectives on Free and Open Source

Software (pp. 1-27). Cambridge: MIT Press.

Lerner, J., \& Tirol, J. (2002). Some simple economics of open source. Journal of Industrial Economics, 50(2), 197-234.

Lorenz, J., Rauhut, H., Schweitzer, F., \& Helbing, D. (2010). How social influence can undermine the wisdom of crowd effect. PNAS, 108(22), 9020-9025.

Lüthje, C. (2004). Characteristics of innovating users in a consumer goods field: An empirical study of sport-related product consumers. Technovation, 24(9), 683-695.

Lüthje, C., Herstatt, C., \& von Hippel, E. (2005). User-innovators and "local" information: The case of mountain biking. Research Policy, 34, 951-965.

Magnusson, M., \& Kristensson, P. (2010). Tuning users' innovativeness during ideation. Creativity and Innovation Management, 19(2), 147-159.

Marchi, G., Giachetti, C., \& de Gennaro, P. (2011). Extending lead-user theory to online brand communities: The case of the community Ducati. Technovation, 31(8), 350-361.

Mollick, E., \& Nanda, R. (2015). Wisdom or madness? Comparing crowds with expert evaluation in funding the arts. Management Science, 62(6), 15331553.

Morrison, P. D., Roberts, J. H., \& von Hippel, E. (2000). Determinants of user innovation and innovation sharing in a local market. Management Science, 46(12), 1513-1527.

Muchnik, L., Aral, S., \& Taylor, S. J. (2013). Social infuence bias: A randomized experiment. Science, 341, 647-651.

Nambisan, S., Agarwal, R., \& Tanniru, M. (1999). Organizational mechanisms for enhancing user innovation in information technology. MIS Quarterly, 23(3), 365-395. 
Noble, J. A. (2012). Minority voices of crowdsourcing: Why we should pay attention to every member of the crowd. In ACM 2012 conference on Computer Supported Cooperative Work Companion (pp. 179-182).

Oliveira, P., \& von Hippel, E. (2011). Users as service innovators: The case of banking services. Research Policy, 40(6), 806-818.

Piller, F., Koch, M., Möslein, K., \& Schubert, P. (2003). Managing high variety: How to overcome the mass confusion phenomenon of customer codesign. In EURAM 2003 Paper Submission Track.

Piller, F., Schubert, P., Koch, M., \& Möslein, K. M. (2005). Overcoming mass confusion: Collaborative customer co-design in online communities. Journal of Computer-Mediated Communication, 10(4).

Piller, F. T., \& Walcher, D. (2006). Toolkits for idea competitions: A novel method to integrate users in new product development. R\&D Management, 36(3), 307-318.

Piller, F. T., \& West, J. (2014). Firms, users, and innovation: An interactive model of coupled open innovation. In H. Chesbrough, W. Vanhaverbeke, \& J. West (Eds.), New Frontiers in Open Innovation (pp. 1-33). Oxford: Oxford University Press.

Pine, J. B. (1993). Mass Customization: The New Frontier in Business Competition. Boston: Harvard Business School Press.

Prügl, R., \& Schreier, M. (2006). Learning from leading-edge customers at The Sims: Opening up the innovation process using toolkits. $R \& D$ Management, 36(3), 237-250.

Rosenberg, N. (1976). Perspectives on Technology. Cambridge: Cambridge University Press.

Russell, B. (1948). Human Knowledge: Its Scope and Limits. London: George Allen \& Unwin Ltd.

Schilling, M. A. (2013). Strategic Management of Technological Innovation (4th ed.). New York: McGraw-Hill/Irwin.

Schreier, M., Fuchs, C., \& Dahl, D. W. (2012). The innovation effect of user design: Exploring consumers' innovation perceptions of firms selling products designed by users. Journal of Marketing, 76(5), 18-32.

Schreier, M., Oberhauser, S., \& Prügl, R. (2007). Lead users and the adoption and diffusion of new products: Insights from two extreme sports communities. Marketing Letters, 18(1-2), 15-30.

Schumpeter, J. A. (1934). The Theory of Economic Development. Harvard: Harvard Business University Press.

Shah, S. K., Smith, S. W., \& Reedy, E. (2012). Who Are User Entrepreneurs? Findings on Innovation, Founder Characteristics, and Firm Characteristics. Kansas City: Kauffman Foundation.

Shah, S. K., \& Tripsas, M. (2007). The accidental entrepreneur: The emergent and collective process of user entrepreneurship. Strategic Entrepreneurship Journal, 1, 123-140. 
Slaughter, S. (1993). Innovation and learning during implementation: A comparison of user and manufacturer innovations. Research Policy, 22(1), 81-95.

Surowiecki, J. (2004). The Wisdom of Crowds. Why the Many are Smarter than the Few and How Collective Wisdom Shapes Business, Economies, Societies, and Nations. New York: Doubleday.

Tapscott, D., \& Williams, A. D. (2006). Wikinomics: How Mass Collaboration Changes Everything: Everything Else. Penguin Group.

Tranfield, D., Denyer, D., \& Smart, P. (2003). Towards a methodology for developing evidence-informed management knowledge by means of systematic review. British Journal of Management, 14(3), 207-222.

Tushman, M. L., Anderson, P., \& O'Reilly, C. A. (1997). Technological cycles, innovation streams, and ambidextrous organizations: Organizational renewal through innovation streams and strategic change. In M. L. Tushman \& P. Anderson (Eds.), Managing Strategic Innovation and Change: A Collection of Readings (pp. 3-23). New York: Oxford University Press.

Vanhaverbeke, W., West, J., \& Chesbrough, H. (2014). Surfing the new wave of open innovation research. In H. Chesbrough, W. Vanhaverbeke, \& J. West (Eds.), New Frontiers in Open Innovation (pp. 1-14). Oxford: Oxford University Press.

von Hippel, E. (1976). The dominant role of users in the scientific instrument innovation process. Research Policy, 5(3), 212-239.

von Hippel, E. (1986). Lead Users: An important source of novel product concepts. Management Science, 32(7), 791-805.

von Hippel, E. (1988). The Sources of Innovation. New York: Oxford University Press.

von Hippel, E. (1994). "Sticky information" and the locus of problem solving: Implications for innovation. Management Science, 40(4), 429-439.

von Hippel, E. (1998). Economics of product development by users: Impact of "sticky" local information. Management Science, 44(5), 629-644.

von Hippel, E. (2005). Democratizing Innovation: Users Take Center Stage. Cambridge, MA: MIT Press.

von Hippel, E. (2007). Horizontal innovation networks - by and for users. Industrial and Corporate Change, 16(2), 293-315.

von Hippel, E. (2011). The User Innovation Revolution. MIT Sloan Management Review.

von Hippel, E., \& Finkelstein, S. N. (1979). Analysis of innovation in automated clinical chemistry analyzers. Science and Public Policy, 6(1), 24-37.

von Hippel, E., \& Katz, R. (2002). Shifting innovation to users via toolkits. Management Science, 48(7), 821-833.

von Hippel, E., \& von Krogh, G. (2003). Open source software and the "private-collective" innovation model: Issues for organization science. Organization Science, 14(2), 208-223. 
von Krogh, G., \& von Hippel, E. (2006). The promise of research on open source software. Management Science, 52(7), 975-983.

Wagner, C., \& Vinaimont, T. (2010). Evaluation the wisdom of crowds. Issues in Information Systems, XI(1), 724-732.

West, J., \& Bogers, M. (2014). Leveraging external sources of innovation : A Review of research on open innovation. Journal of Product Innovation Management, 31(4), 814-831.

\begin{abstract}
Polish)
W obliczu rosnqcej roli użytkowników w procesach innowacyjnych oraz szybko zwiększajqcej się liczby badań w tym obszarze, celem niniejszego opracowania jest wyznaczenie granic rozumienia tego tematu w literaturze. By zrealizować tak zdefiniowany cel badawczy oraz usystematyzować rozważania, autorka odniosła się do czterech podstawowych pytań badawczych: (1) Dlaczego użytkownicy angażuja się w proces tworzenia i dyfuzji innowacji? (2) Kim jest użytkownik-innowator? (3) Jakie typy innowacji powstajq w wyniku działań użytkowników? (4) Jak użytkownicy tworzq innowacje? Na podstawie systematycznego przeglqdu literatury zidentyfikowane zostały cztery strumienie badań nad innowacjami użytkowników, a także możliwe kierunki dalszych prac badawczych w tym obszarze.
\end{abstract}

Słowa kluczowe: ko-kreacja; innowacje oparte na współpracy; masowa kastomizacja; innowacje użytkowników; popytowe podejście do innowacji.

\title{
Biographical note
}

Maria Roszkowska-Menkes - Assistant Professor, Department of Management Theory, Warsaw School of Economics. She specializes in open innovation and CSR, in particular with regard to sustainability innovation and business models and is a lecturer on postgraduate courses in corporate communications and product management. She is also a business trainer in the area of CSR, PR and innovation management and a former promotion coordinator in the Responsible Business Forum - the largest Polish NGO providing in-depth focus on the CSR concept. 